\title{
STRATEGIC MULTICRITERIA DECISION-MAKING PROCESS IN AGRICULTURE
}

\author{
Strahinja Bogdanovićl, Miroljub Hadžić ${ }^{2}$ \\ *Corresponding author E-mail: strahinja.bogdanovic.15@singimail.rs
}

A R T I C L E I N F O
Original Article
Received: 17 Decembar 2018
Accepted: 13 March 2019
doi:10.5937/ekoPolj1901089B
UDC 005.51:338.48

Keywords:

Agriculture, Strategic Decision Making, Net Present Value (NPV), Analytical Hierarchy Process (AHP)

JEL: $Q 10$

\begin{abstract}
A B S T R A C T
The annual plantations in agriculture do not require large investments; therefore financial yields with this type of investments are limited. On the other hand, investment in perennial plantations, such as walnuts, hazelnuts or apples can be significantly higher, but the ROI or the return on such investment is therefore much higher than those on classic crop production. Making complex strategic decisions in agriculture, like whether to invest in an annual or move to perennial plantations, has been out of the sight for economic theorists for a long time. Therefore, the scientific contribution of this article is an effective use of a hybrid model that combines a quantitative method - such as the Net Present Value (NPV), and a qualitative method such as the Analytical Hierarchy Process (AHP) in a multicriteria decision-making environment which proved that choosing the perennial plantations is a better long term investment strategy then the classic crop production.
\end{abstract}

(C) 2019 EA. All rights reserved.

\section{Introduction}

Agriculture is one of the main branches of any industry in the world, and in the Republic of Serbia as well. Lately, small agricultural holdings in the Republic of Serbia have taken a secondary role compared to large agricultural producers who have raised the level of production and trade of agricultural products to a higher level. Desirous of quick results, through the Ministry of Agriculture, the political structures were often inclined to encourage classic crop production that could produce financial effects very quickly. In this way, raising perennial plantations has slid into the second plan, along with the financial potential that it carries. The role of the state could be amplified by promoting insurance in agriculture, and also by financing researches that are not exclusively commercial (Njegomir, Demko-Rihter, 2018).

This research put in the perspective cost-effectiveness of investing in classic crop production, such as maize, wheat, and soybean, in comparison to investments in raising

1 Strahinja Bogdanović, PhD student, Singidunum University, 32 Danijelova Street, +381653004196, e-mail: strahinja.bogdanovic.15@singimail.rs, ORCID ID https://orcid.org/0000-0001-7464-208X

2 Miroljub Hadžić, Full professor, Singidunum University, 32 Danijelova Street, +38163288480 , e-mail: mhadzic@singidunum.ac.rs, ORCID ID https://orcid.org/0000-0002-8009-2026 
perennial plantations such as walnut, hazelnut or apple. Consequently, the profitability of either investment in above-mentioned alternatives will be tested using the Net Present Value (NPV) method, and the Analytical Hierarchy Process (AHP) method in one strategic decision-making process that could help agricultural producers to choose the best alternative.

Many authors have addressed the issue of strategic decision-making in a multi-criteria environment, but there are not many studies that use scientific methods such as the Analytical Hierarchy Process (AHP) in agriculture. This article has the intention to help agricultural holdings, environmental and agricultural economists, as well as managers in agriculture to fully grasp on decision-making processes so they could be in a better position to decide between alternatives in front of them.

\section{Background}

Agriculture depends on a favorable climate, hence is among the sectors of the global economy where most concern currently lies in the context of climate change which is one of the burning issues of the World these days (Islam, 2012). In many countries, intensive crop production has had negative impacts on production, ecosystems, and the larger environment, putting future productivity at risk (Reddy, 2016). In the Republic of Serbia however, crop production is a leading agricultural segment in the flatland areas where the production of maize and wheat takes the primacy. There are two groups of crop producers in the Republic of Serbia: the first group are large agricultural producers (cooperatives and large holdings with several thousand hectares of land and significant processing machinery); and the second group are small agricultural producers (engaged in classical crop production on small areas and plots not more than a few hectares in size). Crop production is a very risky business for small producers because it largely depends on weather conditions, and they are not in the position to leverage their production with plants that do not depend much on weather conditions. For that reason, this research analyzed the classic crop production of maize, wheat and soybean.

\section{Classic crop production}

Maize is one of the most important cultivated plant species. It is the third in the World measured by planted area (after wheat and rice), and second in the World in terms of quantity of the produced grain. Maize is important as a staple crop (mainly in developing countries) but it is also important as animal feed and, increasingly, as biofuel (Reynolds, 2017). In 2001, it became the first crop in the World for the produced grain quantity. In the Republic of Serbia, maize production is the most common. Taking the last 100 years in consideration, the maize production in the World has increased seven times, and two and a half times in Serbia in the past 50 years (Stefanovic et al., 2011).

Wheat is the most important cereal that is produced and sold worldwide. It is used in the food industry mainly to produce bread and other bakery products, and it has been widely used in the pharmaceutical industry. One-quarter of all arable land in the World 
is sown by wheat. It is the main source of human food, because wheat bread is the basic food for $70 \%$ of the human population. It is estimated that almost two-thirds of total wheat production are used for food production; the remaining one-third is used as seeds, fodder, and non-food products. Developing countries are becoming increasingly urbanized and the land for agricultural production is decreasing rapidly. In the Republic of Serbia, in recent years, grain yield has fallen by an average rate of $2.4 \%$ per year, reflecting the economic powerlessness of the producers and the unstable socio-political situation in the country.

Soybean is a plant from the Fabaceae family and is originated from Asia. In order to have successful plant production, it is necessary to select high-yield varieties as well as to implement the correct and timely agro-technical measures. Soybean production is of great importance because it is used both in nutrition and in the pharmaceutical and other industries. Also, soybean is very important for the nitrogen fixation, maintenance of the crops, etc. Soybean takes an ever-increasing place in crop production, so does the products obtained by processing of soybean such as soybean milk, soybean beverages, tofu-soy cheese, pâtés, etc. Soybean production in the Republic of Serbia is growing constantly. The domestic and the European Union market demand for soybean is very high. The Republic of Serbia is one of the largest soybean producers in Europe. Reasons for such a large production are good cultivation varieties, and climate conditions that suit the cultivation of this culture.

Figure 1 - Average annual purchase prices of maize, wheat and soybean, expressed in $R S D$

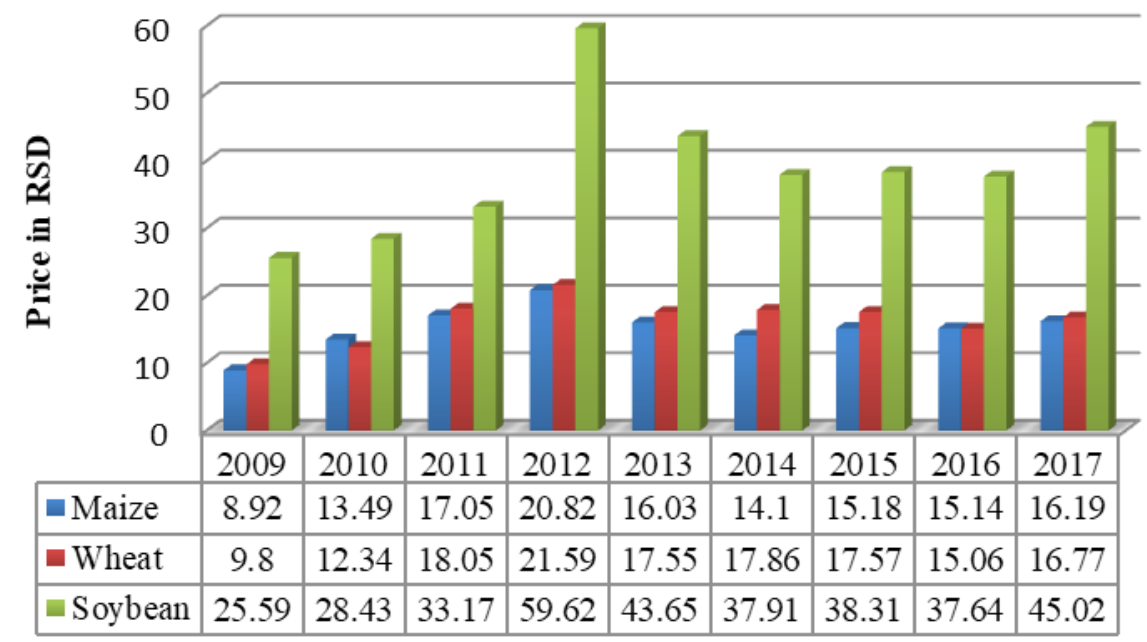

Source: Author's calculations based on available data from the website of the Serbian Republic Statistical Office 
Buying prices of maize in the observed period are ranging from 8.92 RSD per kilogram to 20.82 RSD per kilogram. When it comes to purchasing prices of the wheat, the graphics (Figure 1.) show that the prices have large oscillations and that the market is not well regulated and stable. Prices are ranging from 10 RSD per kilogram to 21.59 RSD per kilogram. The price of soybeans varies from year to year, which creates problems for agricultural producers. The highest price level was present in 2012, where the purchase price was two times higher than the previous three years.

\section{Raising perennial plantations}

Walnuts are plants from the Juglandaceae family. The Latin name Juglans originates from the words "Jovis" and "Glans" which means "Jupiter's gypsum" because the walnut has always been considered the fruit of fertility. The basic advantages of walnut production are easy transportation and low maintenance costs. When it comes to income, walnut can also yield several times higher profits than classic crops. Still, the production of walnuts in the Republic of Serbia is relatively small, and the import of this agricultural product is required. The average purchase prices of walnuts in the Republic of Serbia from 2005 to 2016 were from $1.3 €$ for kilogram to $2.3 €$ for a kilogram. An overview of these prices can be found in the following table and chart (Figure 2.).

Figure 2 - Average annual purchase prices of walnuts, hazelnuts, expressed in RSD

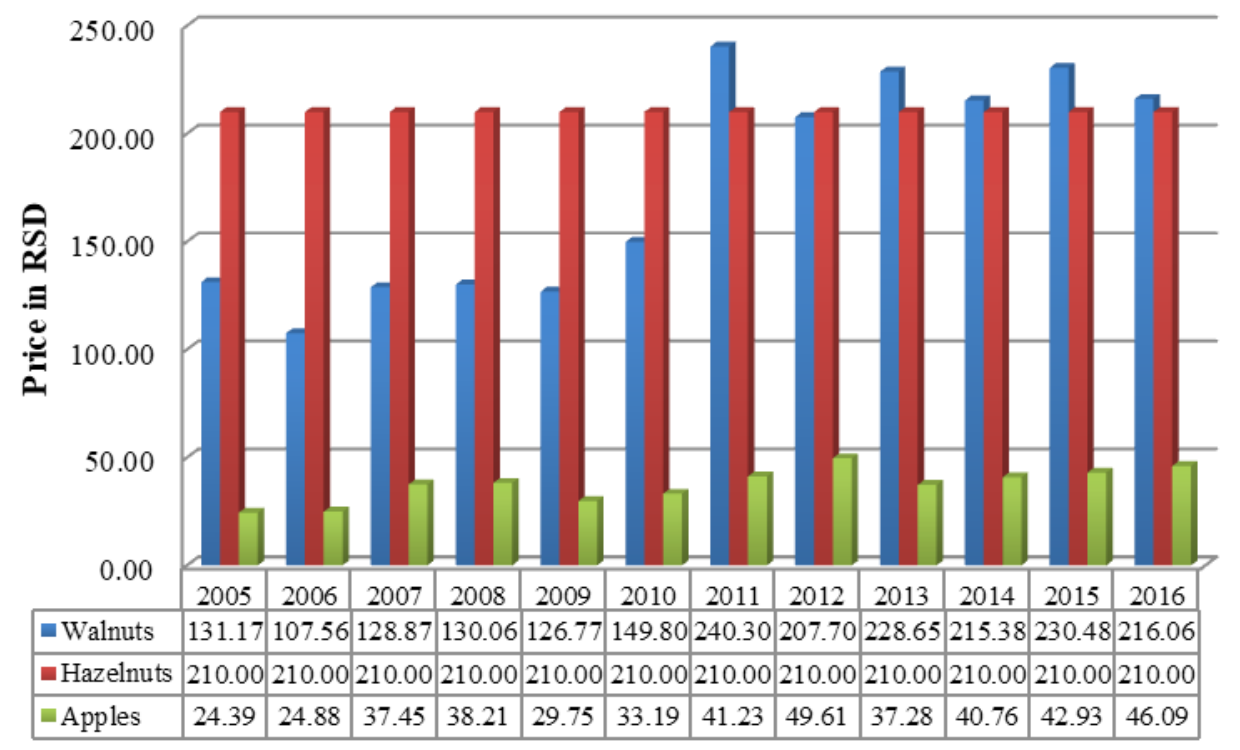

Source: Author's calculations based on available data from the website of the Serbian Republic Statistical Office

Hazelnut is a very old type of fruit. There are some remains of this plant that were found and estimated its origin 8,000 years BC (Šoškić, 2018). In modern conditions, hazelnuts 
are raised to meet the needs of the tree itself but also needs for mechanization on the other hand. Therefore it is mainly grown in the form of a builder or a bush that is up to $4 \mathrm{~m}$ high. When raising such plants, maintenance costs are considerably lower. The hazelnut production and distribution market in the Republic of Serbia is relatively new so the prices range from $1.2 €$ for kilogram to $2.7 €$ for kilogram for hazelnuts in the shell.

Apple is a genus of woody plants from the Rosaceae family. Apple is one of the most widespread fruits in the World (originating from Asia, and the area of China and the Himalayas is characterized by the greatest variety of species). The territory of the Republic of Serbia is one of the most optimal areas in Europe for the production of apples, with its favorable agro-climatic conditions. The average purchase prices of apples in the period from 2005 to 2016 can be found in the table and chart above (Figure 2.).

\section{Materials and methods}

In order to obtain objective results for this paper, a multi-methodological approach was used. Research methods were complementary to each other and chosen based on their significance in assessing the cost-effectiveness of the long-term investment. Consequently, the same methods have the potential to assess the investment alternatives in the strategic decision-making process in agriculture. The Net Present Value method (NPV) was used to evaluate the cost-effectiveness of the investment alternative, while the Analytical Hierarchy Process (AHP) was used as a strategic decision-making tool in a multi-criteria environment.

For the purpose of this research, authors used the AHP-NPV hybrid method in order to analyze two alternatives - the investment in classic crop production (maize, wheat, and soybeans); and the investment in raising perennial plants (walnut, hazelnuts, and apples). In order to obtain the maximum objectivity of the results for the Analytical Hierarchy Process, method of formal or structured interviews was used with key persons in the field of agricultural production and trade. During interviews, all respondents gave the greatest significance to the economic factor of the investment, i.e. its costeffectiveness. Therefore, the detailed analysis of the Net Present Value for the abovementioned alternatives has been carried.

One way to rank, i.e. to evaluate the cost-effectiveness of the investment is by calculating its Net Present Value. This method is dynamic and starts from the future net incomes, and then, using the discount rate, it's reduced to the present value. The aim is to determine whether the present value of cash inflows is sufficient to cover the present value of cash outflows and to achieve planned returns. Net Present Value represents the difference between the present value of the net inflow - the effects of an investment; and the present value of the cash outflow - initial investment itself.

$$
\mathbf{N P V}=\mathbf{V}-\mathbf{I}
$$

$\mathrm{V}$ - discounted net cash inflow (Net Income)

I - initial investment value 
Formula for calculating the present value:

$$
k=\frac{\operatorname{Pr}}{(1+d)^{n}}
$$

where: $k=$ current value, $\operatorname{Pr}=$ annual amount of net cash inflow discounted to the present value, $d=$ discount rate, $n=$ time.

An investment project can be considered acceptable if the present value of its net cash inflows is greater than the present value of the investment in the project, hence if the Net Present Value is greater than zero. Therefore, an investment project is rejected if the present value of its net cash inflow is less than the present value of the investment in the project, or if the Net Present Value is less than zero (Julian, 2011). When calculating NPV in agriculture, the net cash inflow that is going to be generated throughout the period of exploitation must be calculated for a certain moment in time, an operation that is called discounting.

The discount rate reflects the risk of the activity. In this research, a discount rate of $10 \%$ was applied for perennial plantations and $8 \%$ for classic crop production. The discount rate included:

- Country and activity risk (the political risk, regulatory risk and the risk of purchasing power reduction) at a rate of $2 \%$;

- Interest rate (the inflation + real interest rate on investments without the risk) at a rate of $4 \%$;

- Project risk rate (fluctuation in sales prices, yield fluctuations and fluctuations in input prices) at a rate of $2 \%$ to $4 \%$

Analytic Hierarchy Process (AHP) is one of the most famous multi-criteria decisionmaking methods developed by Thomas Saaty in 1980 (Saaty, 2016). AHP is a powerful technique that can help to better express a general decision-making operation by decomposing a complex problem into a multi-purpose hierarchical structure of objective criteria and alternatives (Das \& Saha, 2016). AHP performs comparative comparisons in order to achieve the relative significance of the criteria in each level of the hierarchy. AHP also evaluate alternatives in the hierarchy so that the decision makers could make the best choice among alternatives. This method is an effective decision-making tool especially significant when there is a lot of subjectivity involved. It is very suitable for solving problems where decision-making criteria can be organized hierarchically in sub-criterion (Tuzmen \& Sipahi, 2011).

Analytic Hierarchy Process is used to determine the relative priorities on absolute scales of discrete and continuous paired comparisons on multiple levels of the hierarchy (Vargas, 2017). Determination of the relative priority between a pair within the AHP methodology is achieved by assigning the marks according to the Saaty scale from 1 to 9 (Table 1.) (Saaty, 2016). A parallel matrix of the significance of these factors provides measures for calculating the global importance of the criteria (Das \& Saha, 2016). 
Table 1 - Saaty scale $1 \div 9$ for the comparison of pairs of the decision elements

\begin{tabular}{|c|c|l|}
\hline Saaty's scale & \multicolumn{1}{|c|}{ Definition } & \multicolumn{1}{|c|}{ Explanation } \\
\hline 1 & Same significance & $\begin{array}{l}\text { Two elements have the same significance relative to } \\
\text { the higher level goal }\end{array}$ \\
\hline 3 & Weak dominance & $\begin{array}{l}\text { Experience or reasoning slightly favors one element in } \\
\text { relation to the other }\end{array}$ \\
\hline 5 & Strong dominance & $\begin{array}{l}\text { Experience or reasoning greatly favors one element in } \\
\text { relation to the other }\end{array}$ \\
\hline 7 & Very strong dominance & $\begin{array}{l}\text { Very strong dominance of one element in relation to } \\
\text { the other }\end{array}$ \\
\hline 9 & Absolute dominance & Dominance of the highest degree \\
\hline $2,4,6,8$ & Middle Values & $\begin{array}{l}\text { They are used to show the compromise of the priorities } \\
\text { between the above estimates 1, 3, 5, 7, 9 }\end{array}$ \\
\hline
\end{tabular}

Source: (Saaty, 2016)

The AHP method is based on three principles: first - the structure of the model; second - a comparative assessment of criteria and/or alternatives; third - the synthesis of priorities. In the first step, the problem regarding the decision is structured as a hierarchy (Zyoud et al., 2016). AHP initially breaks down the complex multi-criteria decision-making process in the hierarchy of mutually related elements (criteria, sub-criteria and decision alternatives). In the hierarchy, the goal, decision factors (criteria) and sub-factors (subcriteria), as well as the alternatives, are all arranged in a structure similar to a family tree. The hierarchy has at least three levels: the general goal that needs to be achieved - which is at the top, multiple criteria and sub-criteria that define alternatives - in the middle, and the alternatives at the lowest level (Petruni et al., 2017).

For the purposes of this research, AHP is used to prioritize the criteria that guides strategic decision - whether on a given land, in the long-term period of thirty years or even more, is better to go with the classic crop production or invest in perennial plantings. When the problem is broken down and the hierarchy is constructed, the prioritization procedure begins in order to determine the relative importance of all the criteria. At each level, the criteria are compared in accordance with the degree of their impact to certain criteria at a higher level. In AHP, comparative pairings are based on a standardized scale of nine levels (Table 1.) (Saaty, 2016).

If the $\mathrm{K}=\{\mathrm{Kj} \mid \mathrm{j}=1,2, . . n\}$ is defined as a set of criteria within the appropriate level of hierarchy - Level 1. The results of the comparison of elements at a given level of the hierarchy are placed in the corresponding matrix pairs A $(n x n)$, where each element aij $(i, j=1,2, \ldots n)$ of the matrix A can be defined as the ratio of the criteria weight:

$$
A=\left(a_{i j}\right)_{n \times n}=\left(\begin{array}{ccc}
a_{1} & a_{\mathfrak{1}} & a_{1 n} \\
a_{2} & a_{2} & a_{2 n} \\
1 / a_{n 1} & 1 / a_{n 2} & 1 / a_{n}
\end{array}\right)
$$


At the last step, each matrix is normalized, and then the relative weight for each criterion is found. The relative weightings give the right vector (max) as:

$$
A_{w}=\lambda_{\max } \cdot w
$$

If the comparisons are completely consistent, the matrix $\operatorname{Amax}=n$. In this case, the weight can be obtained by normalizing any of the rows or columns of the matrix A. It should be noted that the quality of the AHP output is relative to the consistency of the paired comparisons. Consistency is defined by the relationship between inputs $A$ : a $i j x$ $a j k=a i k$. The consistency index (CI) can be calculated using the formula below.

In order to calculate the degree of consistency or the Consistency Ratio (CR), the Consistency Index (CI) must first be calculated according to the following relation (Živković, Nikolić, 2006):

$$
\mathrm{CI}=\frac{\lambda_{\max }-n}{n-1}
$$

where $\lambda \max$ is the maximum eigenvalue of the matrix of the comparison $A(n x n)$ :

$$
\left(\begin{array}{ccc}
a_{1} & a_{\mathrm{L}} & a_{1 n} \\
a_{1} & a_{2} & a_{2 n} \\
1 / a_{n 1} & 1 / a_{n 2} & 1 / a_{n}
\end{array}\right)\left[\begin{array}{c}
w_{1} \\
w_{2} \\
\cdot \\
w_{n}
\end{array}\right]=\left[\begin{array}{c}
b_{1} \\
b_{2} \\
\cdot \\
b_{n}
\end{array}\right] \rightarrow\left[\begin{array}{c}
b_{1} / w_{1} \\
b_{2} / w_{2} \\
\cdot \\
b_{n} / w_{n}
\end{array}\right]=\left[\begin{array}{c}
\lambda_{1} \\
\lambda_{2} \\
\cdot \\
\lambda_{n}
\end{array}\right] \rightarrow \lambda_{\max }=\frac{1}{n} \sum_{i=1}^{n} \lambda_{i}
$$

Then, the degree of consistency is determined on the basis of the relation:

$$
C R=\frac{C I}{R I}
$$

where (RI) is the Random Index that depends on number of rows $\mathrm{n}$ in the matrix A, and is taken from the table below (Table 2.) (Saaty, 2016):

Table 2 - Random Index in relation to the number of rows of the matrix

\begin{tabular}{|c|c|c|c|c|c|c|c|c|c|c|}
\hline $\mathbf{n}$ & 1 & 2 & 3 & 4 & 5 & 6 & 7 & 8 & 9 & 10 \\
\hline $\mathbf{R I}$ & 0 & 0 & 0.58 & 0.90 & 1.12 & 1.24 & 1.32 & 1.41 & 1.45 & 1.49 \\
\hline
\end{tabular}

Source: (Saaty, 2016)

If the Consistency Ratio is less than 0.10 (less than 10\%) the result is sufficiently accurate and there is no need for corrections in the comparison and the repetition of calculations. However, if the degree of consistency is greater than 0.10 , the reasons for inconsistency should be determined and the results should be re-analyzed again (Živkovic, Nikolić, 2016). 
In order to obtain more objective results, authors have conducted interviews with relevant persons in the field of agricultural production. Employees of The Department for Agriculture of the city administration of Sombor were interviewed, as well as local agricultural producers, three university professors of the Faculty of Agriculture, and the agricultural engineer from The Ministry of Agriculture of the Republic of Serbia. The choice of these interlocutors was based on their knowledge of the topic, and also their political, social and economic importance for agricultural production in the Republic of Serbia. Each interview lasted about two hours. They were presented with the closed questionnaire related to economic, social, ecological, technological and risk factors of agricultural production. They were also given the freedom to openly discuss many issues regarding the importance of perennial farms for agriculture in the country and the region. Respondents' answers provided excellent insight into the current situation in this market, providing us with a strong basis for the creation of AHP hierarchy. Then, the hierarchy was created as in the following figure (Figure 3.), after which the respondents were presented with the pairwise comparison of the criteria, sub-criteria, and alternatives, so they could prioritize them according to their personal knowledge and belief.

The highest level of the hierarchy is the goal, which in this case is the choice of the strategy for agricultural production for the next thirty years. The second level represents the criteria on the basis of which the priorities of the respondents/advisors will be ranked. Each of the above criteria also contains sub-criteria, that is, the decisionmaking attributes, which are at the Level 3 of this hierarchy. Finally, at the Level 4 of this hierarchy there are alternatives (Figure 3.). In order to avoid confusion by the large number of comparisons, which significantly increases the uncertainty of the process, the alternatives are presented in a group, that is, one alternative for one-year plantings and the other alternative for perennial plantings.

After creating the hierarchy, respondents were presented with the pairwise comparison in Levels 2 and Level 3. For each presented pair, they had to rank the significance of one criteria in comparison to the other, using the Saaty's scale - 1 for the same significance, 3 meaning that the one criteria is slightly more significant than the other, 5 meaning that the one criteria is moderately more significant than the other, 7 giving the great significance to one criteria, and 9 for the absolute dominance of one criteria over the other. Their answers were collected using the laptop and the Microsoft Excel sheet. After that, the average prioritization was calculated for each pair and entered into a Microsoft Excel spreadsheet created using Saaty's AHP prioritization standards. Finally, at the Level 4, the alternatives were also prioritized according to their relevance with each of the sub-criteria from the Level 3. As an end result, the AHP method provided values that clearly indicated the choice of one of the two alternatives. 
Figure 3 - Four levels of the Analytical Hierarchical Process designed for this research

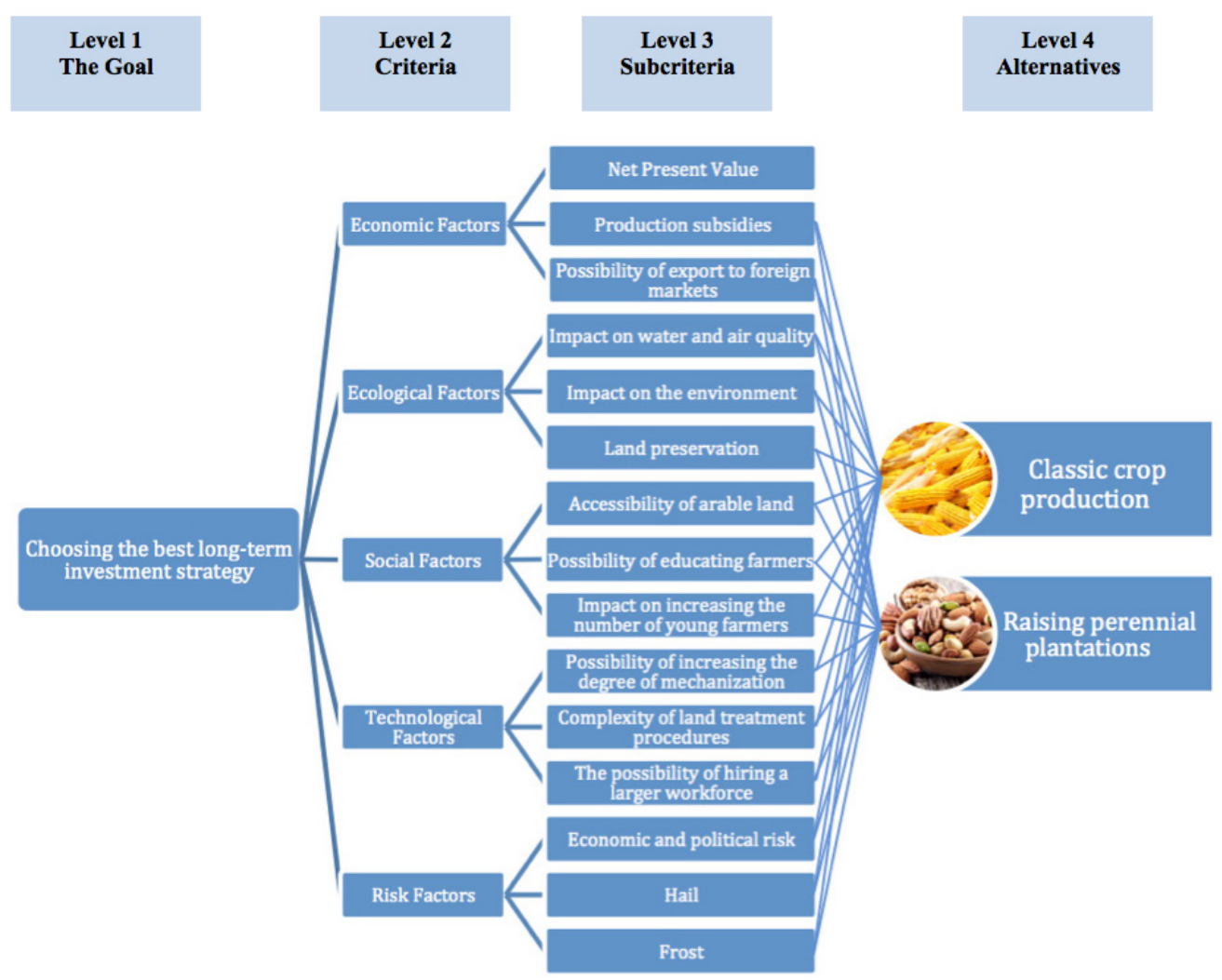

Source: Author's hierarchy design

When considering which projects to follow, and which alternative should be chosen, there is a constant desire for clear, objective and mathematical criteria (Abdel-Basset et al., 2017). However, the decision-making process is, in its entirety, a cognitive and mental process that comes from a choice based on tangible and intangible criteria (Saaty \& Vargas, 2018), arbitrarily chosen by decision-makers. Given any specific situation, making the right decisions is probably one of the most difficult challenges in the field of science, technology, or business (Khan et al., 2014).

\section{Results and Discussion}

After the pairwise prioritization by the respondents, the averages of their responses were rounded to the nearest absolute values for the Saaty scale $(1,3,5,7$ or 9) and entered in a previously created Microsoft Excel spreadsheet, also designed by authors using the Saaty's model for alternatives selection in a multi-criteria environment. Therefore, the local weights of the criteria in Level 2 were obtained. The Economic factor got the highest weight because the respondents gave it the most significance 
relative to other criteria. This seems logical given the fact that the goal is choosing the investment strategy for the next thirty years, which must be profitable. Below (Table 3.) we can see weights of the factors at Level 2 of the hierarchy.

Table 3 - Local weights of the factors at the Level 2 of the hierarchy

\begin{tabular}{|c|c|c|c|c|c|c|c|}
\hline CRITERIA & $\begin{array}{c}\text { Economic } \\
\text { Factors }\end{array}$ & $\begin{array}{c}\text { Ecological } \\
\text { Factors }\end{array}$ & $\begin{array}{c}\text { Social } \\
\text { Factors } \\
\end{array}$ & $\begin{array}{c}\text { Techn. } \\
\text { Factors }\end{array}$ & $\begin{array}{c}\text { Risk } \\
\text { Factors }\end{array}$ & & \\
\hline Economic Factors & 1.000 & 9.000 & 7.000 & 5.000 & 3.000 & & \\
\hline Ecological Factors & 0.111 & 1.000 & 0.333 & 1.000 & 0.333 & & \\
\hline Social Factors & 0.140 & 3.000 & 1.000 & 0.333 & 0.333 & & \\
\hline Techn. Factors & 0.200 & 1.000 & 3.000 & 1.000 & 0.333 & & \\
\hline Risk Factors & 0.333 & 3.000 & 3.000 & 3.000 & 1.000 & & \\
\hline SUM & 1.784 & 17.000 & 14.333 & 10.333 & 3.999 & & \\
\hline CRITERIA & $\begin{array}{c}\text { Economic } \\
\text { Factors }\end{array}$ & $\begin{array}{c}\text { Ecological } \\
\text { Factors }\end{array}$ & $\begin{array}{c}\text { Social } \\
\text { Factors } \\
\end{array}$ & $\begin{array}{c}\text { Techn. } \\
\text { Factors }\end{array}$ & $\begin{array}{c}\text { Risk } \\
\text { Factors } \\
\end{array}$ & $\begin{array}{c}\text { Local } \\
\text { Weight }\end{array}$ & $\begin{array}{l}\text { Consi- } \\
\text { stency }\end{array}$ \\
\hline Economic Factors & 0.561 & 0.529 & 0.488 & 0.484 & 0.750 & 0.562 & 5.317 \\
\hline Ecological Factors & 0.062 & 0.059 & 0.023 & 0.097 & 0.083 & 0.065 & 5.285 \\
\hline Social Factors & 0.078 & 0.176 & 0.070 & 0.032 & 0.083 & 0.088 & 5.370 \\
\hline Techn. Factors & 0.112 & 0.059 & 0.209 & 0.097 & 0.083 & 0.112 & 5.601 \\
\hline Risk Factors & 0.187 & 0.176 & 0.209 & 0.290 & 0.250 & 0.223 & 5.413 \\
\hline SUM & 1.000 & 1.000 & 1.000 & 1.000 & 1.000 & & \\
\hline Consistency Index CI & 0.099 & & & & & & \\
\hline Random Index RI & 1.12 & & & & & & \\
\hline $\begin{array}{l}\text { CONSISTENCY } \\
\text { RATIO CR } \\
\end{array}$ & 0.089 & & & & & & \\
\hline
\end{tabular}

Source: Author's calculations

From the table above we see that the Economic factors with 0.562 have the highest value among the other factors at Level 2 of the hierarchy. Next, there are Risk factors with 0.223 , then the Technological factors with 0.112 , Social factors with 0.088 and finally, Ecological factors with 0.065 . The degree of consistency is below $10 \%$, or less than 0.10 , making this prioritization consistent and credible.

After prioritizing the criteria at Level 2, we conducted the prioritization for all the sub-criteria at Level 3 of the hierarchy. Obtained priorities - the local weight of subcriteria, then had to be compared with the weight of the criteria from the level above in the hierarchy. Multiplying those two weights does this. The reason for that is the need to obtain the global weight of the sub-criteria (sub-factors), in order to determine the significance of each sub-criterion relative to other sub-criteria in the hierarchy, so they could be properly ranked. The global weights of the sub-criteria, or their overall significance in the hierarchy, are shown below in (Table 4.).

In the following table (Table 4.), we can also see that the sub-factor Net Present Value has the highest global weight of 0.408 . This means that in the overall analytical hierarchy process, this decision-making attribute should have the most influence on 
the final choice of the alternative. Also, given its more pronounced global weight in relation to all other sub-factors, the method of calculating the Net Present Value for each alternative had to be included in this research. By practicing the multidisciplinary approach to this research, the authors have provided the verification for the results and quantitatively confirmed the justification of the alternative selection using the Analytical Hierarchical Process.

Table 4 - Total weight of sub-factors at the Level 3 of the hierarchy

\begin{tabular}{|c|c|c|c|c|}
\hline CRITERIA & $\begin{array}{l}\text { WEIGHT } \\
\text { OF THE } \\
\text { CRITERIA }\end{array}$ & SUB-CRITERIA & $\begin{array}{c}\text { LOCAL } \\
\text { WEIGHT } \\
\text { OF THE } \\
\text { SUB- } \\
\text { CRITERIA }\end{array}$ & $\begin{array}{c}\text { GLOBAL } \\
\text { WEIGHT OF } \\
\text { THE SUB- } \\
\text { CRITERIA }\end{array}$ \\
\hline \multirow{3}{*}{$\begin{array}{l}\text { ECONOMIC } \\
\text { FACTORS }\end{array}$} & \multirow{3}{*}{0.562} & Net Present Value & 0.725 & 0.408 \\
\hline & & Production subsidies & 0.081 & 0.046 \\
\hline & & $\begin{array}{l}\text { Possibility of export to foreign } \\
\text { markets }\end{array}$ & 0.194 & 0.109 \\
\hline \multirow{3}{*}{$\begin{array}{l}\text { ECOLOGICAL } \\
\text { FACTORS }\end{array}$} & \multirow{3}{*}{0.065} & Impact on water and air quality & 0.255 & 0.017 \\
\hline & & Impact on the environment & 0.107 & 0.007 \\
\hline & & Land preservation & 0.638 & 0.041 \\
\hline \multirow{3}{*}{ SOCIAL FACTORS } & \multirow{3}{*}{0.088} & Accessibility of arable land & 0.193 & 0.017 \\
\hline & & Possibility of educating farmers & 0.083 & 0.007 \\
\hline & & $\begin{array}{l}\text { Increasing the number of } \\
\text { young farmers }\end{array}$ & 0.724 & 0.064 \\
\hline \multirow{3}{*}{$\begin{array}{c}\text { TECHNOLOGICAL } \\
\text { FACTORS }\end{array}$} & \multirow{3}{*}{0.112} & $\begin{array}{c}\text { Increasing the degree of } \\
\text { mechanization }\end{array}$ & 0.656 & 0.073 \\
\hline & & $\begin{array}{l}\text { Complexity of land treatment } \\
\text { procedures }\end{array}$ & 0.158 & 0.018 \\
\hline & & $\begin{array}{l}\text { The possibility of hiring a } \\
\text { larger workforce }\end{array}$ & 0.187 & 0.021 \\
\hline \multirow{3}{*}{ RISK FACTORS } & \multirow{3}{*}{0.223} & Economic and political risk & 0.714 & 0.159 \\
\hline & & Hail & 0.143 & 0.032 \\
\hline & & Frost & 0.143 & 0.032 \\
\hline
\end{tabular}

Source: Author's calculations

The next step in this process was to analyze each of the alternatives from Level 4 of the hierarchy (Figure 3.). This had to be done through the lens of all fifteen sub-criteria from Level 3. In this sense, local weights of alternatives were first determined, and then compared with the global weights of all sub-factors from Level 3. Multiplying local values of alternatives with global values of each sub-factor, we obtained the global weights of alternatives in relation to all sub-factors at the Level 3 of the hierarchy.

After the summation of the alternative's global weights, the result suggested that the Alternative 2 was the better choice (Table 5.). The second alternative has a significantly higher weight than the first one, and accordingly, it can be concluded that in the Republic of Serbia, based on the prioritization by interviewed experts, raising the 
perennial plantations is a far more profitable investment for farmers than the classic crop production. Below (Table 5.) we can see that the Alternative 2 have 0.670 total weights, and Alternative 1 have 0.380 total weights.

Table 5 - Global weights of alternatives at the Level 4 of the hierarchy

\begin{tabular}{|c|c|c|c|c|c|c|}
\hline CRITERIA & $\begin{array}{c}\text { WEIGHT } \\
\text { OF THE } \\
\text { CRITERIA }\end{array}$ & $\begin{array}{c}\text { SUB- } \\
\text { CRITERIA }\end{array}$ & \begin{tabular}{|c|} 
LOCAL \\
WEIGHT \\
OF THE \\
SUB- \\
CRITERIA
\end{tabular} & $\begin{array}{c}\text { GLOBAL } \\
\text { WEIGHT } \\
\text { OF THE } \\
\text { SUB- } \\
\text { CRITERIA }\end{array}$ & \begin{tabular}{|c|} 
ALT. 1 \\
CLASSIC \\
CROP \\
PRODUCT. \\
GLOBAL \\
WEIGHT \\
\end{tabular} & $\begin{array}{c}\text { ALT. } 2 \\
\text { RAISING } \\
\text { PERENN. } \\
\text { CROPS } \\
\text { GLOBAL } \\
\text { WEIGHT }\end{array}$ \\
\hline \multirow{3}{*}{$\begin{array}{l}\text { ECONOMIC } \\
\text { FACTORS }\end{array}$} & \multirow{3}{*}{0.562} & $\begin{array}{l}\text { Net Present } \\
\text { Value }\end{array}$ & 0.725 & 0.408 & 0.051 & 0.357 \\
\hline & & $\begin{array}{l}\text { Product. } \\
\text { subsidies }\end{array}$ & 0.081 & 0.046 & 0.011 & 0.034 \\
\hline & & $\begin{array}{c}\text { Poss. of export } \\
\text { to foreign } \\
\text { markets }\end{array}$ & 0.194 & 0.109 & 0.027 & 0.082 \\
\hline \multirow{3}{*}{$\begin{array}{c}\text { ECO. } \\
\text { FACTORS }\end{array}$} & \multirow{3}{*}{0.065} & $\begin{array}{l}\text { Impact on water } \\
\text { and air quality }\end{array}$ & 0.255 & 0.017 & 0.008 & 0.008 \\
\hline & & $\begin{array}{c}\text { Impact on the } \\
\text { environment }\end{array}$ & 0.107 & 0.007 & 0.003 & 0.003 \\
\hline & & $\begin{array}{c}\text { Land } \\
\text { preservation }\end{array}$ & 0.638 & 0.041 & 0.010 & 0.031 \\
\hline \multirow{3}{*}{$\begin{array}{c}\text { SOCIAL } \\
\text { FACTORS }\end{array}$} & \multirow{3}{*}{0.088} & $\begin{array}{c}\text { Accessibility of } \\
\text { arable land }\end{array}$ & 0.193 & 0.017 & 0.013 & 0.004 \\
\hline & & $\begin{array}{c}\text { Possibility } \\
\text { of educating } \\
\text { farmers }\end{array}$ & 0.083 & 0.007 & 0.002 & 0.005 \\
\hline & & $\begin{array}{l}\text { Increasing the } \\
\text { No.of young } \\
\text { farmers }\end{array}$ & 0.724 & 0.064 & 0.016 & 0.048 \\
\hline \multirow{3}{*}{$\begin{array}{l}\text { TECHN. } \\
\text { FACTORS }\end{array}$} & \multirow{3}{*}{0.112} & $\begin{array}{l}\text { Increasing the } \\
\text { degree of mech. }\end{array}$ & 0.656 & 0.073 & 0.055 & 0.018 \\
\hline & & $\begin{array}{l}\text { Complexity of } \\
\text { land treatment }\end{array}$ & 0.158 & 0.018 & 0.013 & 0.004 \\
\hline & & $\begin{array}{l}\text { Possibility of } \\
\text { hiring a larger } \\
\text { w.f. }\end{array}$ & 0.187 & 0.021 & 0.016 & 0.005 \\
\hline \multirow{5}{*}{$\begin{array}{c}\text { RISK } \\
\text { FACTORS }\end{array}$} & \multirow{3}{*}{0.223} & $\begin{array}{c}\text { Economic and } \\
\text { political risk }\end{array}$ & 0.714 & 0.159 & 0.133 & 0.027 \\
\hline & & Hail & 0.143 & 0.032 & 0.016 & 0.016 \\
\hline & & Frost & 0.143 & 0.032 & 0.005 & 0.027 \\
\hline & & & & SUM & 0.380 & 0.670 \\
\hline & & & & CHOICE & & $\mathbf{X}$ \\
\hline
\end{tabular}

Source: Author's calculations 
It has been previously noted that the Economic factors from Level 2 of the AHP hierarchy was given the highest weight by expert's prioritization. That means they were given the highest significance in relation to other criteria. Consequently, the subfactor of Net Present Value was given the most significance, largely because it can be the best predictor of the cost-effectiveness of a long-term investment. For this reason, Net Present Value calculations were carried for each of the alternatives, for a period of thirty years, on an area of 10 hectares.

Classic crop production is analyzed in a single case. It starts with the assumption that the land is in the ownership of the agricultural producer itself, and that the sowing will be done using the crop rotation system - maize, then the soybean and wheat, and that the farmer himself will acquire the necessary machinery for the basic land cultivation. Following example will reflect the true state of the agricultural production on small farms in the Republic of Serbia.

Total annual costs for the investments in production of maize on 10 hectares amounts roughly to 665.000 RSD, then, 645.000 RSD for soybean and 372.000 RSD for the wheat. These costs include all the material costs along with the costs of sowing and cultivation. Agricultural producers need to have machinery for the cultivation, and most of them do. Mechanization is very old in the Republic of Serbia, where most of the machines are inherited. It has been calculated that the cost of procurement of such machinery for a period of 30 years amounts to 2.160.000 RSD, while the cost of maintenance for the dilapidated machinery during the period of exploitation is 1.153.843 RSD. Purchase prices for crop yields were calculated based on the average and the trend of the purchase prices over the period of past 7 years - maize 16 RSD / $\mathrm{kg}$, wheat $17 \mathrm{RSD} / \mathrm{kg}$ and soybean $40 \mathrm{RSD} / \mathrm{kg}$, and the yields per hectare have been calculated according to the yields trend in the Republic of Serbia.

In order to calculate the Net Present Value, Net Income was discounted at a rate of $8 \%$ for a period of thirty years. Then, the initial investment in procurement and the maintenance of mechanization was deducted. Total discounted value of the Net Income during the period of exploitation of maize, soybean, and wheat was 7.587.238 RSD, and initial investment in procurement and the maintenance of mechanization of 3.313.843 RSD was then deducted. By subtracting these two values we've got the Net Present Value. Since the difference between these two values is positive, the investment is justified.

$$
\mathrm{NPV}=\text { 7.587.238 RSD }- \text { 3.313.843 RSD }=\text { 4.273.395 RSD }
$$

Second alternative -the investment in raising perennial plantations was analyzed in detail for each plant because of the need for selection of one of the sub-alternatives - walnut, hazelnut or apple. The analysis also began with the assumption that the agricultural holding owns 10 hectares of land. It also included all investment costs on one side, and all revenues on the other side, for a period of thirty years. Below are calculations for obtaining the Net Present Value for each plant. The final results are presented within the table of the Net Present Value for all alternatives and subalternatives latter in the conclusion (Table 6.). 
As with every perennial plantation, walnut plantations also need large investments. It is necessary to pass five to six years for the perennial planting of walnuts to achieve full fertility. For this reason, ratio of the investment and the waiting period for full fertility is longer than with apple, apricot, peach, and other fruit species. Contrary to this deficiency, the exploitation period of this fruit is up to two times longer than the above-mentioned species. In order to protect such large investment, it is necessary to properly fence the plantation and preserve it in the ripening period. After initial investment, and a waiting period of five years, a period of full fertility begins in the $6^{\text {th }}$ year. In this period, financial investments are also very high and include the cost of materials, services and labor costs. Total costs of production of walnuts on 10 hectares of land for a period of 30 years of full exploitation is 32.637.000 RSD.

Net result is calculated by deducting the costs of regular production from the total revenues for a given year. Purchase price was set to $230 \mathrm{RSD} / \mathrm{kg}$ (price of the walnuts in a shell). This price was calculated based on a trend of movement of walnut prices in a period from 2005 to 2016. It should be emphasized that there are three periods of fertility: the period of early fertility, the period of full fertility and the period of declining fertility. The yield of the genus depends directly on the period of fertility.

Total discounted value for Net Income obtained during the period of exploitation of walnut is 50.705.437 RSD. Initial investment of 15.094.804 RSD was then deducted. By subtracting these two values, the Net Present Value was obtained. Since the difference was positive, the investment is fully justified. The amount of NPV for walnut could even be higher, but for this case, the period of exploitation was calculated for 30 years, although it is known that plantations of walnut could be exploited for up to 50 years.

\section{$\mathrm{NPV}=$ 50.705.437,08 RSD - 15.094.804 RSD = 35.610.633,08 RSD}

Same calculations were carried for perennial plantations of hazelnut. Total discounted value for Net Incomes during the period of hazelnut exploitation was 45.054.196 RSD. After the subtraction of the initial investment prior to the period of exploitation, which amounts to 14.927.306 RSD, Net Present Value for the production of hazelnut for a period of 30 years was 30.126.890 RSD.

\section{$\mathrm{NPV}=$ 45.054.196,46 RSD - 14.927.306 RSD = 30.126.890,46 RSD}

When it comes to the production of apples for a period of 25 years, Net Present Value was obtained in the following way. Total discounted value for Net Incomes during the period of apple exploitation amounts to 140.435.093 RSD. Initial investment that amounts to 52.948.101 RSD was then deducted. Subtracting these two values, Net Present Value result was obtained, and was by far the highest among all the other subalternatives. Investment in apples was not only justified, but also desirable, since the Net Present Value was87.486.992,01 RSD.

$$
\mathrm{NPV}=\mathbf{1 4 0 . 4 3 5 . 0 9 3 , 0 1} \mathrm{RSD}-\mathbf{5 2 . 9 4 8 . 1 0 1} \mathrm{RSD}=\mathbf{8 7 . 4 8 6 . 9 9 2 , 0 1} \mathrm{RSD}
$$


AHP prioritization pointed that the second altern0ative - raising the perennial plantations - was a better choice. The analysis for the Net Present Value has enabled the quantification of AHP method's priorities and additionally contributed to the decisionmaking process of choosing the best long-term investment strategy. The following table (Table 6.) shows the Net Present Values of both the first alternative - raising annual plantations of maize, soybean, and wheat in a crop rotation, and the second alternative - raising perennial plantations of walnuts, hazelnuts or apples. So, Analytic Hierarchy Method provided the base for choosing the best alternative, and the Net Present Value method helped additionally in the process of choosing the best sub-alternative.

Table 6 - Ranking of the Net Present Values for all sub-alternatives involved in this research

\begin{tabular}{|c|c|c|c|c|c|}
\hline Alternatives & Culture & $\begin{array}{c}\text { Initial } \\
\text { Investments }\end{array}$ & $\begin{array}{c}\text { Discounted } \\
\text { Incomes }\end{array}$ & $\begin{array}{c}\text { Net Present } \\
\text { Value (NPV) }\end{array}$ & $\begin{array}{c}\text { Ranking } \\
\text { according to } \\
\text { NPV }\end{array}$ \\
\hline Alternative 1 & $\begin{array}{c}\text { Classic crop } \\
\text { production }\end{array}$ & 3.313 .843 & 7.587 .238 & $\mathbf{4 . 2 7 3 . 3 9 5}$ & 4. \\
\hline \multirow{2}{*}{ Alternative 2 } & Walnut & 15.094 .804 & 50.705 .437 & $\mathbf{3 5 . 6 1 0 . 6 3 3}$ & 2. \\
\cline { 2 - 6 } & Hazelnut & 14.927 .306 & 45.054 .196 & $\mathbf{3 0 . 1 2 6 . 8 9 0}$ & 3. \\
\cline { 2 - 6 } & Apple & 52.948 .101 & 140.435 .093 & $\mathbf{8 7 . 4 8 6 . 8 8 2}$ & 1. \\
\hline
\end{tabular}

Source: Author's calculations

\section{Conclusion}

The results have shown that the AHP prioritizing in the multi-criteria decision-making process, regarding the choice of the investment strategy in an agricultural production could clear many doubts when deciding upon alternatives for a period of 30 years. Interviewed experts gave the most significance to Economic factors of the investment, and to the Net Present Value as a sub-factor, so authors decided to use AHP-NPV method to choose the best investment alternative.

Calculations have shown (Table 6.) that all three sub-alternatives of the second alternative have significantly higher Net Present Values than the classic crop production. However, classic crop production carries a lower risk of investment as well as far lower initial investment. If an agricultural holding does not have the ability to raise a loan or access funds for greater initial investment, it will not be able to think about and calculate second alternative. Furthermore, in addition to Financial factors, there are many other factors that can influence the final decision, such as the type of land, the climate and the location of the land, the proximity of roads, etc. The choice of sub-alternative could also become a new goal for the next AHP prioritization process.

This research has proven that the application of AHP method in the decision-making process regarding long-term investments in an agricultural multi-criteria environment is not only possible but also desirable. Combined method that involve experts and collect their opinions into a system where their preferences are quantified, and where their 
subjective opinions become objective values, clarifies the decision-making process, turning it into indispensable tool in an agricultural production. The creation of such AHP-NPV hybrid method in order to facilitate investment decisions in agriculture is also a great scientific contribution of this research.

\section{Acknowledgements}

Authors would like to thank The Department for Agriculture of the city administration of Sombor, the local agricultural producers, university professors of the agricultural faculty that participated as interviewers in this research, and agricultural engineers from The Ministry of Agriculture of the Republic of Serbia, for facilitating the creation of the AHP hierarchy.

\section{Conflict of interests}

The authors declare no conflict of interest.

\section{References}

1. Abdel-Basset, M., Mohamed, M., Zhou, Y., \& Hezam, I. (2017). Multi-criteria group decision-making based on neutrosophic analytic hierarchy process. Journal of Intelligent \& Fuzzy Systems, 33(6), 4055-4066.

2. Das, D., \& Saha, A. (2016). Analytical hierarchy process based supplier selection methodology: a framework and application. International Journal of Reliability and Safety, 10(2), 125-144.

3. Islam, M. A. (2012). Agricultural adaptation to climate change: Issues for developing countries. ABC Journals, 30.

4. Julian, J.W. (2011). AgProfit ${ }^{\mathrm{TM}}$ : a net present value and cash flow based decision aid for agriculture producers, Agricultural Finance Review, Vol. 71 Issue: 3, pp.366-378

5. Khan, S., Dulloo, A. B., \& Verma, M. (2014). Adaptation of the AHP as MultiCriteria Decision Making Approach and Testing the Original AHP over Two Evaluative Criteria. International Journal of Scientific \& Engineering Research, 5(6), 963-968.

6. Njegomir, V. \& Demko-Rihter, J. (2018) The problem of the demand for crop insurance: The case of Serbia, Ekonomika poljoprivrede, 2018, vol. 65, iss. 3, pp. 995-1014

7. Petruni, A., Giagloglou, E., Douglas, E., Geng, J., Leva, M. C., \& Demichela, M. (2017). Applying Analytic Hierarchy Process (AHP) to choose a human factors technique: Choosing the suitable Human Reliability Analysis technique for the automotive industry. Safety Science.

8. Reddy, P. P. (2016). Sustainable intensification of crop production. Springer, Singapore 
9. Reynolds, M.P. (2017). Climate Change and Crop Production, CABI Publishing, Wallingford, United Kingdom

10. Saaty, T. L., \& Vargas, L. (2018). Decision Making with the Analytic Hierarchy Process. 2008. Int. J. Services Sciences

11. Saaty, T.L., (2016) The analytic hierarchy and analytic network processes for the measurement of intangible criteria and for decision-making. Multiple criteria decision analysis (pp. 363-419). Springer, New York, NY.

12. Šoškic M., (2018), Walnut and hazelnut, Parthenon, Belgrade [in Serbian: Orah i leska, Partenon, Beograd]

13. Stefanović L., Simić M., Šinžar B. (2011). Control of weeds in maize agroecosystem, Corn Institute ZemunPolje, Belgrade [in Serbian: Kontrola korova u agroekosistemu kukuruza, Institut zakukuruz Zemun Polje, Beograd]

14. Tuzmen, S. \& Sipahi, S. (2011). A multi criteria factor evaluation model for gas station site selection. Journal of Global Management. 2. 12-21.

15. Vargas, L. G. (2017), The Legacy Of The Analytic Hierarchy/Network Process. International Journal of the Analytic Hierarchy Process, 9(3).

16. Živković, Ž. i Nikolić, Đ. (2016). Fundamentals of Strategic Management School of Mathematics, University of Belgrade, Technical Faculty in Bor[in Serbian:Osnove matematičke škole strategijsko gmenadžmenta, Univerzitet u Beogradu, Tehničkifakultet u Boru]

17. Zyoud, S. H., Kaufmann, L. G., Shaheen, H., Samhan, S., \& Fuchs-Hanusch, D. (2016). A framework for water loss management in developing countries under fuzzy environment: Integration of Fuzzy AHP with Fuzzy TOPSIS. Expert Systems with Applications, 61, 86-105. 